\title{
Masa Tenang Kampanye Politik Pada Media Sosial Dan Ketentuan Pemidanaanya
}

\author{
Oleh : Patrick Corputty
}

corputtyp@gmail.com

Ilmu Hukum, Fakultas Hukum, Universitas Pattimura

\begin{abstract}
ABSTRAK
Kampanye adalah suatu saluran atau program yang esensial dalam mendukung pesta pemilihan umum, kampanye adalah suatu cara untuk memperkenalkan diri serta memaparkan sebuah visi dan misi. Kampanye pada era modern telah merambah mengikuti kemajuan teknologi. Media sosial menjadi salah satu wujud perkembangan tersebut, sekarang banya calon wakil rakyat yang berkampanye melalui media sosial, kampanye yang dilakukan cendeung melampaui batasanbatasan yang telah ditentukan, batasan yang dimaksudkan ialah masa tenang, kampanye yang dilakukan melalui media sosial tidaklagi menghiraukan masa tenang, padahal Undang-Undang secara tegas telah menetapkan ketentuan pidana bagi siapa saja yang melakukan pelanggaran termasuk melakukan kampanye pada masa tenang.
\end{abstract}

Kata Kunci: Kampanye, Masa Tenang dan Pemidanaan

\begin{abstract}
The campaign is a channel or essential program in supporting general election party, the campaign is one of the ways to introduce oneself and assert their vision and mission. The campaign in the modern era has evolved by following technology advancement. Social Media become one of those development forms, now a lot of representative candidates use it for the campaign, which sometimes the campaign did outreach the specified limitations: electoral silence. The campaign through social media no longer obey electoral silence, whereas laws expressly specify the criminal provision to whoever that violate include those who do the campaign in this period.
\end{abstract}

Keywords: Campaign, Electoral Silence, Criminalisation 


\section{A. Pendahuluan}

Pemilihan umum adalah pesta demokrasi tiap lima tahun yang selalu diselenggarakan guna memilih wakil rakyat dan juga pemimpin kepala daerah hingga memilih kepala negara. Pemilu dimaknai sebagai prosedur untukmencapai demokrasi atau merupakan prosedur untuk memindahkan kedaulatan rakyat kepada kandidat tertentu untuk menduduki jabatan-jabatan politik ${ }^{1}$. Pemilu menunjukkan bahwa kekuasaan politik berasal dari rakyat dan dipercayakan demi kepentingan rakyat, dan bahwa kepada rakyatlah para pejabat bertanggungjawab atas tindakan- tindakannya ${ }^{2}$.

Moh. Mahfud mengatakan bahwa kedaulatan rakyat mengandung pengertian adanya pemerintahan dari, oleh dan untuk rakyat, menunjukkan bahwapemerintahan dari rakyat

${ }^{1}$ Veri Junaidi, 2009, Menata Sistem Penegakan Hukum Pemilu Demokratis Tinjauan Kewenangan MK atas Penyelesaian Perselisihan Hasil Pemilu (PHPU). Jurnal Konstitusi Volume 6, Nomor 3, hal 106

${ }^{2}$ Beetham, David dan Boyle, Kevin, 2000, Demokrasi: 80 Tanya Jawab, terjemahan Bern Hidayat, Kanisius, Yogyakarta, hal 172. mengandung pengertian yang berhubungan dengan pemerintahan yang sah dan diakui (legitimate government) di mata rakyat ${ }^{3}$.

Pada umumnya di negara yang menganut paham demokrasi, pemilu dipandang sebagai lambang, dan dipakai sebagai tolak ukur demokrasi pada negara itu sendiri. Untuk itu pemilu merupakan suatu yang melekat pada prinsip demokrasi itu sendiri. Pada umumnya pemilu tidaklah terpisahkan dari proses serta tahapan yang dinamakan kampanye.

Kampanye adalah suatu program yang dirancang unntuk mendukung pesta rakyat dengan tajuk pemilihan umum. Kampanye merupakan ajang mempromosikan dan mengenalkan diri dan menyampaikan ide dan gagasan berupa visi dan misi. Pengertian kampanye secara umum adalah sebuah bentuk komunikasi dengan tujuan mengenalkan,mempromosikan atau mempublikasikan beberapa hal yang bertujuan untuk mereput kepercayaan masyarakat. Pesan dan

${ }^{3}$ Moh. Mahfud MD, 1999 Pergulatan Politik dan Hukum. Yogyakarta: Gama Media. 
informasi pada saat berkampanye biasanya berisi keunggulan dari setiap individu atau lebih bersifat personal. Jadi intinya bahwa proses kampaye itu adalah proses yang penting, jadi dikalau proses ini dilewati atau tidak dilakukan dengan baik maka dapat di simpulkan tokon politik akan sulit untuk dikenal oleh halayak banyak.

Kampanye menurut UndangUndang Republik Indonesia Nomor 7 Tahun 2017 tentang Pemilihan Umum memberi pengertian bahwa kampanye pemilu adalah kegiatan peserta Pemilu atau pihak lain yang ditunjuk oleh peserta pemilu untuk menyakinkan pemilih dengan menawarkan visi, misi, program dan/atau citra diri peserta pemilu. Menurut Undang-Undang Pemilu, Kampanye Pemilu merupakan bagian dari pendidikan politik masyarakat dan dilaksanakan secara bertanggung jawab. Pada Pasal 275 UndangUndang Pemilu telah mengatur tentang metode yang digunakan untuk melakukan kampanye, yang bunyinya :

Kampanye Pemilu sebagaimana dimaksud dalam Pasal 267 dapat dilakukan melalui
a. pertemuan terbatas;
b. pertemuan tatap muka;
c. penyebaran bahan Kampanye Pemilu kepada umum;
d. pemasangan alat peraga ditempat umum;
e. media sosial
f. iklan media massa cetak, media massa elektronik, dan internet;
g. rapat umum;
h. debat Pasangan Calon tentang materi Kampanye Pasangan calon; dan
i. kegiatan lain yang tidak melanggar larangan Kampanye Pemilu dan ketentuan peraturan perundang- undangan.

$$
\text { Pada masa digital seperti }
$$
sekarang ini kampanye pada media sosial dianggap lebih evektif mengambil hati para pemilih terkususnya pemilih kaum milenial, yang mana pada kenyataannya hampir sebagian besar adalah pengguna media sosial.Media sosial pada masa kampanye sering digunakan untuk menyebarkan visi dan misi dari tiap calon. Namun dalam hal berkampanye tentu ada batasanya tersendiri, dalam Undang-Undang Pemilu pada pasal 276 dijelaskan bahwa kampanye pemilu dilaksanakan 
3 (tiga) hari setelah penetapan daftar calon dan berakhir pada 3 hari sebelum hari pemungutan suara yang dikenal dengan nama masa tenang.

Selanjutnya yang menjadi permasalahan dalam penulisan ini ialah penentuan 3 hari sebagai masa tenang belumlah terealisasi dengan baik dan maksimal terkhususnya pada media sosial, hal ini banyak ditemui dalam pemilu serentak 2019, yang mana masih banyak akun yang menyebarkan poster dan selebaran berupa ajakan yang mana semestinya tidak lagi dilakukan pada masa tenang. Oleh sebab itu pada penulisan kali ini akan membahas tentang bagaimana ketentuan pidana terhadap kampanye pada media sosial dimasa tenang

\section{B. Hasil dan Pembahasan}

Proses pemilihan politik adalah proses menyeleksi dan menjaring calon-calon pemimpin masa depan yang berkompeten serta memenuhi prasyarakatan sesuai dengan peraturan perundangan yang berlaku.

Meskipun mekanisme pemilihan umum ini sudah berulangkali dilakukan, namun tetap saja ada beberapa informasi seputar hal-hal yang perlu mendapat pemahaman dan serta pengertian dari masyarakat. Untuk itu proses pemberian informasi ini perlu dilakukan guna memberikan pencerahan dan pemahaman tentang apa yang perlu mendapat perhatian penting bagi masyarakat guna mensukseskan proses pemilihan ini, selanjutnya upaya ini dilakukanagar supaya proses pemilihan dapat menghasilkan output atau tokoh politikterpilih yang siap melangkah sebagai pemimpin pada suatu wilayah, serta siap menjalankan tanggung jawabnya yang baru.

Berkembangnya era digital mendorong banyak pilihan baru terkait dengan model pemberian informasi bagi masyarakt, sehingga model-model konfensional seolahsolah kurang diminati. Realitasnya sering dijumpai dalam masa-masa kampanye politik para kandidat calon kepala daerah yang sedang maju dalam kompetisi pemilihan kepala daerah, maupun kandidat calon presiden dalam Pilpres, memanfaatkan media sosial sebagai sarana komunikasi politiknya kepada 
khalayak calon pemilih ${ }^{4}$.

\section{Media Sosial Sebagai Sarana Kampanye}

Kemajuan teknologi mendorong manusia untuk melangkah dan bergerak maju, dengan kemajuan teknologi ada banyak hal yang memperhadapkan kita dengan sesuatu yang berdampak positif, serta berdampak negatif. Teknologi juga erat kaitannya dengan kemampunan manusia dalam menerima perubahan. Kemajuan teknologi juga dirasakan dalam kontestasi Pemilu yakni berubahnya gaya berkampanye yang semula menggunakan metode konfensional kini berkampanye lebih gencar terjadi pada media sosial.

Andreas Kaplan dan Michael Haenlein mendefinisikan media sosial sebagai sebuah kelompok aplikasi berbasis internet yang dibangun diatas dasar ideologi dan teknologi Web 2.0, dan memungkinkan penciptaan dan pertukaran user-generated content.

\footnotetext{
${ }^{4}$ Budiyono, (2016, Oktober) Media Sosial sebagai Komunikasi Politik Menjelang PILKADA DKI JAKARTA
} 2017, Jurnal Komunikasi, 47-62
Web 2.0 menjadi platform dasar media sosial. ${ }^{5}$

Pengelompokan media sosal dalam terdiri dari beberapa bentuk bentuk berbeda diantaranya sosial network, weblobgs, sosial blogs, bookmark sosial dan masih banyak lagi. Menurut Kaplan dan Haenlein ada enam jenis media sosial: proyek kolaborasi (misalnya, wikipedia), blog dan microblogs (misalnya, twitter), komunitas konten (misalnya, youtube), situs jaringan sosial (misalnya facebook, instagram), virtual game (misalnya world of warcraft), dan virtual social (misalnya, second life $)^{6}$

Media sosial adalah sebuah situs yang dibuat dengan tujuan agar dapat dipakai untuk menuliskan basis data atau berita tentang kepribadian seseorang. Salah satu media sosial terbesar adalah facebok., twitter, dan instagram. Bila dibandingkan dengan media konfensional seperti media cetak dan media broadcast, media sosial hadir dengan menggunakan

${ }^{5}$ Gusti Ngurah Aditya Lesmana, Tesis: Analisis Pengaruh Media Sosial Twitter Terhadap Pembentukan Brand Attachment (Studi: PT. XL AXIATA), (Program Magister Manajemen, Fakultas Ekonomi, Universitas Indonesia). hal, 10-11 ${ }^{6}$ Ibid 
layanan internet yang sudah dapat dipastikan lebih maju dari media konfensional dimaksud. Media sosial membuka ruang bagi siapapun yang berminat untuk berkontribusi secara terbuka, dan saling memberi dan membagi informasi dengan waktu yang instan dan cepat.

Jadi media sosial merupakan media online yang menggandeng teknologi internet untuk melakukan interaksi sosial, ahrinya megubah model komunikasi model lama menjadi model dialog interaktif yang menimbulkan timbal balik. Dengan berkembangnya era digital, dapat dipastikan media sosial akan menjadi sebuah sarana penting dan efektif dalam proses komunikasi politik khususnya dalam hal berkampanye, sehingga kampamnye pemilu yang menjadi ajang promosi antara tokoh politik dan masyarakat dapat terjadi dan berlangsung dengan baik dan maksimal. Untuk itu diharapkan melalui media sosial komunikasi yang dibangun antara tokoh politik dengan masyarakat pendukungnya dapat membentuk opini publik untuk mendorong setiap visi misi dari tokoh politik tersebut, sekaligus memobilisasi dukungan politik secara baik dan
terukur.Penggunaan media sosial dinilaitelah meningkatkan jaringan komunikasi politik, relasi politik dan partisipasi politik masyarakat dalam pesta demokasi yang diberi nama pemilu ini.Semua itu dapat dibuktikan ketika dijumpai pada masa-masa kampanye politik para kandidat calon Kepala Daerah yang sedang maju dalam kompetisi pemilihan Kepala Daerah (Pilkada), maupun kandidat calon presiden dalam Pilpres, dan dalam pemilihan anggota legislatif(Pileg). ${ }^{7}$

Gaya berkampanye melalui media sosial sudah dilakukan pada Pemilu 2014, yang kemudian pada Pemilu serentak 2019 metode yang sama kembali digunakan, mungkin ini bercermin pada keberhasilannya merebut hati pemilih pada Pemilu 2014 yang lalu. Ketertarikan calon wakil rakyat menggunakan media sosial sebagai sarana promosi dilihat sebagai fenomena yang menarik dikarenakan hampir sebagian besar

\footnotetext{
${ }^{7}$ IkeAtikah Ratnamulyani dan Beddy Iriawan Maksudi. (2018, Juli) PERAN MEDIA SOSIAL DALAM PENINGKATAN PARTISIPASI PEMILIHPEMULA DIKALANGAN PELAJAR DI KABUPATENBOGOR, Jurnal Ilmu-ilmu Sosial dan Humaniora 20(2), hal 154-161.
} 
yang menggunakan strategi seperti

ini, keunggulan media sosial dalam menyebar luaskan informasi dianggap sebagai langkah maju dalam berkampanye di era modernisasi. Sebut saja beberapa aplikasi penyedia layanan media sosial seperti Facebook, Instagram, Whatsapp yang penggunanya sungguh sangatlah banyak di negara ini, jadi dengan begitu banyaknya pengguna membuat para calon wakil rakyat ini berlomba-lomba menyampaikan visi dan misinya sehingga aplikasi-aplikasi diatas menjadi tempat bertempurnya berbagai calon wakil rakyat.

\section{Ketentuan Pidana Pada Masa Tenang}

1. Pengertian TindakPidana

Kata "tindak pidana" merupakan terjemahan dari "strafbarrrfeit". Perkataan "feit" berarti sebagian dari kenyataan atau "eengedeelte van

werkwlijkheid",sedangkan

"strafbaar" berarti dapat dihukum. Sehingga sacara harfiah strafbaar feit dapat diterjemahkan sebagai sebagian dari suatu kenyataan yang dapat dihukum. ${ }^{8}$

$$
\text { Menurut Pompe }
$$

perkataan strafbaar feit secara teoritis dapat dirumuskan sebagai suatu pelanggaran norma (gangguan terhadap tertib hukum) yang dengan sengaja ataupun tidak dengan sengaja telah dilakukan oleh seorang pelaku, dimana penjatuhan hukuman terhadap pelaku tersebut adalah perlu demi terpeliharanya tertib hukum dan terjaminnya kepentinganumum. ${ }^{9}$

\section{Menurut}

Hermien

Hadiati

Koeswadji sebagaimana dikutip oleh A. Fuad

UsfadanTongat, "Dalamkepus takaanhukumpidana, istilah"ti ndakpidana"merupakan istilah yang dipakai sebagai terjemahan dari istilah bahasa

${ }^{8}$ P. A. F. Lamintang. 1990. DasarDasar Hukum Pidana Indonesia. Bandung: Sinar Baru. hlm. 181

${ }^{9}$ Ibid. hlm 182. 
Belanda strafbaarfeit". ${ }^{10}$

Kata "starfbaarfeit" diartikan lebih khusus oleh Evi Hartanti, yaitu "Dalam bahasa Belanda, strafbaarfeit terdapat dua unsur pembentuk kata, yaitu strafbaar dan feit. Kata feit dalam bahasa Belanda diartikan sebagian dari kenyataan, sedang strafbaar berarti dapat dihukum, sehingga secara harafiah, kata strafbaarfeit berarti sebagian dari kenyataan yang dapat dihukum".11

Sedangkan menurut Moeljatno sebagaimana dikutip oleh Evi Hartanti, "Tindak pidana merupakan perbuatan yang dilarang oleh suatu aturan hukum, larangan yang mana disertai sanksi berupa pidana tertentu bagi barangsiapa yang melanggar aturan tersebut". ${ }^{12}$

${ }^{10}$ Fuad Usfa dan Tongat. 2004. Pengantar Hukum Pidana. Malang: UMM Press. hlm. 31

11 Evi Hartanti. 2007. Tindak Pidana Korupsi. Jakarta. Sinar Grafika.hlm.5

12 Moeljatno. 1993. Asas-asas Hukum Pidana. Jakarta. Rineka Cipta.hlm.7
2. Masa Tenang dan Ketentuan Pidananya

Sesuai dengan Pasal 1 Angka 36 Undang-Undang Pemilihan Umum, masa tenang adalahmasa tidak dapat digunakan untuk melakukan aktivitas kampanye pemilihan umum. Masa tenang menurut Undang-Undang Pemilu

Pasal 167 ayat (4) adalah merupakan satu tahapan penyelenggara Pemilu yang mana proses tahapannya ialah meliputi

a. perencanaan program dan anggaran serta penyusunan peraturan pelaksanaan Penyelenggaraan

Pemilu;

b. pemutakhiran data Pemilih dan penyusunan daftar Pemilih;

c. pendaftaran dan verifikasi Peserta Pemilu; 
d. penetapan Peserta

Pemilu;

e. penetapan jumlah kursi dan penetapan daerah pemilihan;

f. pencalonan Presiden dan Wakil Presiden serta anggota DPR, DPD, DPRD provinsi, dan DPRD kabupaten/kota;

g. masa Kampanye

Pemilu;

h. Masa Tenang;

i. pemungutan dan penghitungan suara;

j. penetapan hasil Pemilu; dan

k. pengucapan sumpah/janji Presiden dan Wakil Presiden serta anggota DPR, DPD, DPRD provinsi, dan DPRD

kabupaten/kota.

Selanjutnya larangan terkait dengan masa tenang dapat dilihat pada Pasal 278 ayat (2) yang mana bunyinya,
Selama masa tenang, pelaksana, peserta, dan/atau tim Kampanye Pemilu Presiden dan Wakil Presiden dilarang menjanjikan atau memberikan imbalan kepada Pemilih untuk:

a. tidak menggunakan hak pilihnya;

b. memilih Pasangan Calon;

c. memilih Partai Politik Peserta Pemilu tertentu;

d. memilih calon anggota DPR, DPRD provinsi, dan DPRD kabupaten /kota tertentu; dan/atau

e. memilih calon anggota DPD tertentu.

Pada undang-undang yang sama larangan terkait masa tenang juga terdapat pada Pasal 287 ayat (5) dan Pasal 449 ayat (2) yang masing-masing bunyinya:

\section{Pasal 287 ayat (5)}

Media massa cetak, media daring, media sosial, dan lembaga penyiaran selama masa tenang dilarang menyiarkan berita, iklan, rekam jejak Peserta Pemilu, atau bentuk lainnya yang mengarah pada kepentingan Kampanye Pemilu yang menguntungkan atau merugikan peserta Pemilu.

\section{Pasal 449 ayat (2)}

Pengumuan hasil surveinatau jajak pendapat tentang Pemilu sebagaimana 
dimaksud pada ayat (1) dilarang dilakukan pada masa tenang.

Dari berbagai larangan yang telah dipaparkan diatas tentunya masing-masing memiliki sanksi pidana yang berbeda-beda, contohnya saja sanksi bagi pelanggar Pasal 278 ayat (2) seperti yang tertuang pada Pasal 523 ayat (2) yang bunyinya:

\section{Pasal 523 ayat (2)}

"Setiap pelaksana, peserta dan/atau tim Kampanye Pemilu yang dengan sengaja pada masa tenang menjanjikan atau memberikan imbalan uang ataupun materi lainnya kepada pemilih secara langsung ataupun tidak langsung sebagaimana dimaksud dalam Pasal 278 ayat (2) dipidana dengan pidana penjara paling lama 4 (empat) tahun dan denda paling banyak Rp. 48.000.000,00 (empat puluh delapan juta rupiah).

Ketentuan pidana pada Pasal 523 ayat (2) tentunya berbeda dengan ketentuan pidana pada pasal 509 yang memberi sanksi bagi pelanggar pasal 449 ayat (2) sebagaimana tertulis:

\section{Pasal 509}

Setiap orang yang mengumumkan hasil survei atau jajak pendapat tentang Pemilu dalam masa tenang sebagaimana dimaksud dalam pasal 449 ayat (2), dipidana dengan pidana penjara paling lama 2 (dua) tahun dan denda paling banyak Rp. 24.000.000,00 (dua puluh empat juta rupiah).

Selanjutnya ketika
memabahas terkait dengan kampanye pada media sosial di pemilu serentak 2019 ini, dapat dipastikan bahwa media sosial digunakan sebagai tempat untuk menyebarkan alat peraga kampanye yang berisi visi dan misi dari setiap tokoh politik yang mana akan tampil sebagai calon wakil rakyat. Sehingga permasalahan yang sering terjadi ialah kampanye yang dilakukan cenderung melampaui kententuan serta batasan-batasan yang terkandung di dalam Undang-Undang Pemilu. Batasan yang dimaksudkan dalam penulisan ini ialah batasan terkait dengan masa tenang yang ditetapkan sesuai dengan undang-undang yakni 3 hari sebelum hari pemungutan suara. Hal ini dapat dilihat pada Pemilu tahun ini yang mana banyak 
sekali akun-akun pada aplikasiaplikasi media sosial seperti Facebook, Instagram, Whatsapp dan masih banyak aplikasi yang lain yang tidak mengindahkan batas waktu yang telah ditetapkan oleh undang-undang Pemilu ini. Sehingga masa tenang pun masih dipakai untuk terus membagikan profil serta visi dan misi dari tiap-tiap calon wakil rakyat.

Tentunya bagi setiap orang yang melakukan kampanye di masa tenang, berarti telah melakukan kampanye di luar jadwal waktu yang ditetapkan oleh UU Pemilu maupun Peraturan KPU, sehingga sanksinya adalah sebagaimana disebut dalam Pasal 492 yang sebagaimana ketentuannya di bawah ini.

\section{Pasal 492}

Setiap orang yang dengan sengaja melakukan Kampanye Pemilu di luar jadwal yang telah ditetapkan oleh KPU, KPU Provinsi, dan KPU Kabupaten/Kota untuk setiap Peserta Pemilu sebagaimana dimaksud dalam Pasal 276 ayat (2), dipidana dengan pidana kurungan paling lama 1 (satu) tahun dan denda paling banyak
Rp12.000.000,00 (dua belas juta rupiah).

Namun walaupun sanksi ini telah secara jelas tertuang didalam Undang-Undang Pemilu, namun masih saja ada yang tidak menghiraukannya. Seperti yang telah saya jelaskan diatas masih saja ada akun yang dengan sengaja maupun tidak sengaja secara terus-menerus gencar melakukan kampanye melalui media sosial.Ini berarti bahwa setiap pelanggaran terhadap norma dan ketentuan perundang-undangan yang berlaku juga merupakan sebuah tindak pidana yang mana konsekuansinya dapat dipidana sesuai dengan ketentuan yang berlaku.

$$
\begin{aligned}
& \text { Selanjutnya walaupun } \\
& \text { sudah dilakukannya berbagai } \\
& \text { usaha prefentif oleh Bawaslu } \\
& \text { dengan menghimbu kepada } \\
& \text { seluruh pengguna media sosial } \\
& \text { namun nampaknya himbauan } \\
& \text { semacam ini tidaklah dianggap } \\
& \text { penting sehingga tidak digubris } \\
& \text { dan dipahami dengan baik. Hal } \\
& \text { ini mungkin saja karena } \\
& \text { kampanye lawat media sosial }
\end{aligned}
$$


tidak dinilai sebagai suatu pelanggaran Pemilu, ataupun masih kurangnya pemahaman publik terbaik dengan sanksi bagi pelanggar aturan kampanye Pemilu pada masa tenang.

\section{Penutup}

Kesimpulannya ialah masih lemahnya pemahaman publik terkait dengan sanksi yang akan diberikan bagi setiap pelanggar UndangUndang Pemilu khususnya terkait dengan proses kampanye pada masa tenang yang sasarannya ialah media sosial. Sehingga masih banyak orang maupun tim kampanye terus menerus gencar berkampanye pada masa tenang, hal ini tentunya membuat kita berpikir apakah ancaman pemidaan terkait dengan permasalahan ini dirasa biasa-biasa saja sehingga orang ataupun tim kampanye cenderung mengabaikan ketentuan atauran ini.

Kemudiaan sebagai soslusinya disarankan agar ketika masa tenang dirasa perlu disosialisasikan secara baik dan menyeluruh agar pemahaman publik pun dapat dibentuk. Selanjutnya bawaslu perlu menjalin kerja sama dengan beberapa penyedia layanan media sosial agar sebelum dilakukannya sanksi pidana ada lagi upaya lain seperti pemblokiran dan penonaktifan akunakun yang berkamanye pada masa tenang berdasarkan laporan dari akun atau pengguna lainnya.

\section{Daftar Pustaka}

Beetham. (2000). Demokrasi : Tanya Jawab, Terjemahaan Bern . Yogyakarta: Kanisius.

Budiyono. (2017). Media Sosial Sebagai Komunikasi Politik Menjelang Pilkada DKI Jakarta. Jurnal Komunikasi .

Hartanti, E. (2007). Tindak Pidana Korupsi. Jakarta: Sinar Grafika.

Junaidi, V. (2009). Menata Sistem Penegakan Hukum Pemilu Demokratis Tinjauan Kewenangan MK atas Penyelesiaian Perselisihan Hasil Pemilu. Jurnal Konstitusi .

Lamintang, P. (1990). Dasar-Dasar Hukum Pidana Indonesia. Bandung : Sinar Baru.

Mafud, M. M. (1999). Pergulatan Politik dan Hukum. Yogyakarta: Gama Media. 
Moeljatno. (1993). Asas-asas Hukum Pidana. Jakarta: Rineka Cipta.

Ratnamuyani, I. A., \& Maksudi, B. I. (2018). Peran Media Sosial Dalam

Peningkatan Partisipasi Pemilih Pemula di Kalangan Pelajar Kabupaten Bogor.

Jurnal Ilmu-ilmu Sosial dan Humaniora .

Usfa, F. (2004). Pengantar Hukum Pidana. Malang: UMM Press. 